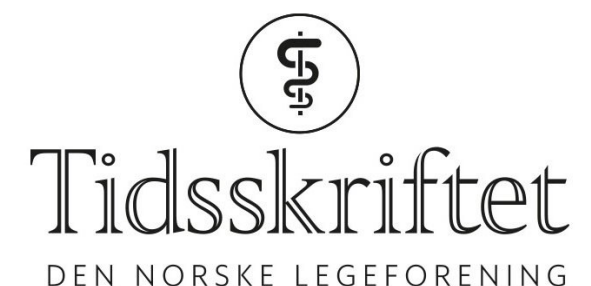

DEN NORSKE LEGEFORENING

\title{
Klager fra pasienter må håndteres bedre
}

PERSONLIGE OPPLEVELSER

\section{ANONYM}

Forfatteren ønsker å være anonym, men vedkommendes identitet er kjent for redaksjonen.

Pasienter skal selvsagt kunne klage. Men saksbehandlingen kan ikke være så dårlig at den setter legers liv og helse i fare.

Min mann og jeg har vært leger i et langt yrkesliv og har vært glad for det. Nå var tiden kommet for å nyte «livets dessert» som spreke pensjonister med mange interesser og et godt forhold til barn og barnebarn.

En dag dumper et brev ned i postkassen, adressert til min mann. Det har vinduskonvolutt og er fra Fylkesmannen. Brevet informerer om at en pasient hevder å ha vært utsatt for et seksuelt overgrep under en konsultasjon en del år tilbake i tid. Man ber om journalnotat og en kommentar til påstanden. Hva klagen konkret går ut på, opplyses ikke. Brevet avsluttes med at saksbehandlingstiden vil være åtte måneder.

Journalnotatet blir skaffet til veie. Det blir sendt Fylkesmannen sammen med et tilsvar som utdyper pasientens problemer og som kategorisk benekter at noe ureglementert har funnet sted.

Så er det fortsatt sju måneder og tre uker igjen av den antatte saksbehandlingstiden. Hva skal man som anklaget lege gjøre i den perioden? Legge det hele på is og fortsette livet som før? Det skjer i vårt tilfelle ikke. Min mann grubler: Hva i all verden er det klagen går ut på? Og: Var svarbrevet godt nok? Ivaretok han pasienten nok i det han skrev? Og hva med den aktuelle konsultasjonen - hadde den ikke vært faglig god nok? Ingen pasient skulle behøve å misforstå på denne måten, osv. osv.

Dagene blir lange, nettene enda lengre, for søvnen uteblir. Min mann isolerer seg. Han grubler over sakens konsekvenser og ser for seg fengselsstraff, økonomisk ruin og tap av all ære. Han selv vet at påstanden om overgrep er totalt grunnløs - men hvordan skal det kunne bevises? Her står det påstand mot påstand, og han vet ikke engang hva det er snakk om. Han er maktesløs. Og det er fortsatt sju måneder til noe kan forventes å skje.

Jeg skjønner snart at min mann er klinisk deprimert. Psykiater blir kontaktet og medikamenter blir skrevet ut. De sikrer søvn, men legger et tungt lokk av sedasjon over dagene. Vi ser for oss at det skal være sånn de neste seks og en halv månedene. Men slik går det ikke. En kveld jeg kommer hjem finner jeg min mann dypt komatøs. På kjøkkenbordet ligger avskjedsbrevet.

De første dagene er det usikkert hvilken vei det kommer til å gå. Til vår store glede våkner 
han opp, men tankene er like mørke. Et månedslangt sykehusopphold følger. Og fortsatt er det fire måneder igjen av saksbehandlingstiden når han skrives ut. Når omsider denne perioden lakker mot slutten, ser vi godt etter i postkassa hver dag. Og en dag finner vi det etterlengtede brevet i vinduskonvolutt! Kanskje kan vi nå avslutte dette marerittet og gå videre i livet?

Dessverre. Brevet inneholder ingen vurdering, men informerer om at saken oversendes Helsetilsynet. En måneds tid senere kommer en ny vinduskonvolutt, denne gang fra nevnte tilsyn, som opplyser at saksbehandlingstiden vil være ca. seks måneder. Rykk tilbake til start.

De seks månedene skal vise seg å bli til nærmere et år. Da, endelig, kommer den faglige vurderingen fra Helsetilsynet med følgende konklusjon: Man finner ikke grunn til å fatte noe administrativt vedtak i saken. Vurderingen virker solid og grundig, og kan neppe ha vært faglig vanskelig. Men det tok altså drøyt halvannet år å få den gjort.

Vurderingen virker solid og grundig, og kan neppe ha vært faglig vanskelig. Men det tok altså drøyt halvannet år å få den gjort

Enhver klage mot en lege, uansett hvor triviell, er en potent trigger av psykisk sykdom (1). En undersøkelse av nesten 8 ooo engelske leger fant at $18 \%$ av dem som nylig hadde blitt utsatt for en klage, rapporterte moderat til alvorlig depresjon og $15 \%$ moderat til alvorlig angst (2). Lidelsestrykket var sterkere hvis klagen var av alvorlig art, og mange hadde selvmordstanker. I en intervjustudie fortalte allmennleger utsatt for klager om en første fase preget av sjokk, panikk og tap av kontroll. Etter hvert overtok søvnvansker, depressive og suicidale tanker samt tvil om egen profesjonell rolle og faglig kompetanse (3).

Selvsagt skal enhver pasient ha rett til å klage på enhver lege dersom vedkommende mener at noe ikke er som det skal være. Leger både gjør og tar feil. Og de fleste som har jobbet lenge i klinisk virksomhet forstår at en pasient kan misforstå, feiltolke eller selvhenføre, og at dette kan resultere i en uberettiget klage. Det er greit. Men vi fikk erfare at prosessen vi har her i landet for å håndtere en slik klage på langt nær er god nok - den er faktisk skandaløst dårlig og direkte livsfarlig.

Vi fikk erfare at prosessen vi har her i landet for å håndtere en slik klage på langt nær er god nok - den er faktisk skandaløst dårlig og direkte livsfarlig

En saksbehandlingstid på drøyt halvannet år er utilbørlig og burde være unødvendig. Som pårørende og observatør på første benk sitter jeg igjen med flere spørsmål. For det første: Hvordan i all verden kan Fylkesmannen bruke åtte måneder på å oversende saken til en høyere instans, Helsetilsynet? Det var ikke gjort noe fors $ø \mathrm{k}$ på en tilsynsfaglig vurdering hos Fylkesmannen, så en slik oversendelse burde vel kunne gjøres i løpet av en uke? For det andre: Å bli anklaget for et seksuelt overgrep er en ekstrem belastning for en lege og å være i en slik uavklart situasjon i svært lang tid uten annen mulighet enn å vente innebærer en betydelig risiko for liv og helse (1-3). Det må være en regel å flytte slike saker «framover i køen» på bekostning av mer trivielle saker. Når den faglige vurderingen i min manns sak først fant sted, var den utmerket og den tok neppe mange dager. Men å la en slik sak ligge «i en skuff» i et år før man tar den fram er ikke bra nok.

I sitt brev til min mann beklager Helsetilsynet den lange saksbehandlingstiden. Med god grunn - den hadde på hengende håret kostet ham livet. Og den påførte en hel familie halvannet år i unntakstilstand, hvor alt annet ble satt på vent. Jeg unner ingen å gjennomgå det samme. Det må kunne gjøres bedre enn dette.

LITTERATUR:

1. Gerada C. We need a complaints code of conduct. BMJ 2019;364: 159. [PubMed][CrossRef]

2. Bourne T, Wynants L, Peters M et al. The impact of complaints procedures on the welfare, health and 
clinical practise of 7926 doctors in the UK: a cross-sectional survey. BMJ Open 2015; 5: eoo6687. [PubMed][CrossRef]

3. Jain A, Ogden J. General practitioners' experiences of patients' complaints: qualitative study. BMJ 1999; 318: 1596-9. [PubMed][CrossRef]

Publisert: 2. august 2019. Tidsskr Nor Legeforen. DOI: 10.4045/tidsskr.19.0356

(C) Tidsskrift for Den norske legeforening 2020. Lastet ned fra tidsskriftet.no 